\title{
Botany
}

\section{Severe frost but not shade could limit the future growing season of Erythronium americanum}

\begin{tabular}{|c|c|}
\hline Journal: & Botany \\
\hline Manuscript ID & cjb-2021-0131.R1 \\
\hline Manuscript Type: & Article \\
\hline $\begin{array}{r}\text { Date Submitted by the } \\
\text { Author: }\end{array}$ & 24-Aug-2021 \\
\hline Complete List of Authors: & $\begin{array}{l}\text { Tessier, Jack; State University of New York College of Technology at } \\
\text { Delhi, Liberal Arts and Sciences; }\end{array}$ \\
\hline Keyword: & $\begin{array}{l}\text { climate change, forest understory, freezing, leaf lifespan, spring } \\
\text { ephemeral }\end{array}$ \\
\hline $\begin{array}{r}\text { Is the invited manuscript for } \\
\text { consideration in a Special } \\
\text { Issue? : }\end{array}$ & Not applicable (regular submission) \\
\hline
\end{tabular}

\section{SCHOLARONE \\ Manuscripts}




\section{Abstract}

Changes in climate are leading to modifications in the timing of seasonal events such as migrations and flowering. Erythronium americanum (trout lily) can break bud early in response to warming, but changes to its growing season may be limited by early shade from canopy trees and frost. I experimentally assessed the impact of shade and frost on senescence in $E$. americanum and descriptively monitored the response of E. americanum to vernal air and soil temperatures in a garden setting. Early shade did not affect the timing of senescence.

Experimental exposure to frost resulted in increased leaf damage, earlier senescence, and greater corm death than in control plants. Despite ten days in which the air temperature dropped below freezing, there was no evidence of leaf damage in the field. These results suggest that early shade from canopy trees will not hasten the end of the future growing season for E. americanum, but that late frost could bring about early senescence if that frost is sufficiently hard.

\section{Keywords}

climate change, forest ecosystem, forest understory, freezing, leaf lifespan, Liliaceae, senescence, spring ephemeral, trout lily, deciduous forest

\section{Introduction}

Global climate change is causing modifications to patterns of temperature and precipitation around the world (e.g., Di Cecco and Gouhier, 2018; Konapala et al., 2020). In particular, these changes are affecting the timing of transitions between seasons, with spring temperatures arriving earlier than typical in some areas (Monahan et al., 2016; Christiansen, Markstrom and Hay, 2011). As a result, some species have altered the timing of their migrations (Gill et al., 2014; Somveille et al., 2020), flowering (CaraDonna, Iler, and Inouye, 2014; Bertin, 
47 2015), bud break (Sivadasan et al., 2017; Ladwig et al., 2019), and leaf senescence (Gallinat, 48 Primack and Wagner, 2015; Wu et al., 2018).

One species that is capable of adjusting its timing of bud break is Erythronium

50 americanum Ker. Gawl. (Werier, 2017). This species is native to the northeast United States

51 (Siccama, Bormann and Likens, 1970; Stokes, Philpott and Culley, 2019) and is a spring

52 ephemeral, with leaves emerging shortly after snowmelt and senescing after canopy leaf out

53 (Muller, 1978; Tessier, 2008). This early activity makes this species valuable to wildlife as a

54 source of pollen (Thomson, 1986; Austen, Lin and Forrest, 2018). Vernal activity in E.

55 americanum also makes this species important to nutrient cycling and retention (Muller, 1978;

56 Lerat et al., 2002). When exposed to early warming, E. americanum can hasten its leaf out,

57 suggesting that early spring warming could expand its growing season (Tessier, 2019). What is

58 not clear is what ecological factors could limit the expansion of the growing season for $E$.

59 americanum.

This study addressed the question: if E. americanum can emerge early in response to

61 early spring warming, will other factors prevent it from extending its growing season? I

62 hypothesized that early shade from canopy trees and late spring frost could shorten the duration

63 of the growing season for leaves of E. americanum that emerge early (Inouye 2000, 2008). This

64 hypothesis led to two predictions. First, shaded leaves will senesce earlier than those in full sun.

65 Second, leaves that emerge early will suffer death if exposed to extended freezing temperatures.

\section{Materials and methods}

67

I assessed the effect of early shade on leaf senescence experimentally. Thirty 
70 shade component of this project than the frost component due to logistical constraints during the

71 COVID-19 Pandemic (Korbel and Stegle, 2020; Myers et al., 2020). Each subpopulation was at

72 least $1 \mathrm{~m}$ from its neighbor to ensure different genets. Cube-shaped shade structures $(15 \mathrm{~cm}$ on

73 all sides) were constructed of PVC tubing and greenhouse shade cloth. At least 10 leaves of each

74 subpopulation were covered by a shade structure and at least 10 other leaves of each

75 subpopulation were left uncovered. I measured light intensity on cloudless days between 10 AM

76 and 2 PM with a LI-COR LI-250 Light Meter (LI-COR Biosciences, Lincoln, NE, USA) inside

77 (shade) and outside (control) of the shade structures on April 28, 2020 and after the tree canopy

78 closed in both background light (forest floor in the shade of the tree canopy) and sunflecks (small

79 areas of high light intensity where the tree canopy does not provide background levels of shade)

80 on June 8, 2020. Twice per week, I assessed the subpopulations for senescence, documenting

81 when it began and was complete for each treatment and replicate. Beginning of senescence was

82 recognized as yellowing or browning of the leaf and end of senescence was recognized as the

83 leaves being brown and no longer upright.

I also assessed the response of E. americanum to frost experimentally. On November 21,

852019 , I collected 120 corms from a second growth hardwood forest near Delhi, NY (42 14'33”'

$\left.86 \mathrm{~N}, 7^{\circ} 56^{\prime} 03^{\prime \prime} \mathrm{W}\right)$. These corms were planted in seed starting trays in forest soil collected from

87 the $\mathrm{O}_{\mathrm{a}}$ layer (where corms usually are found, within the bottom $10 \mathrm{~cm}$ of the organic soil

88 horizons) of the same forest. The trays were placed in a refrigerator at $5^{\circ} \mathrm{C}$ and watered when

89 the soil surface appeared dry (approximately weekly). Corms were assigned to a treatment in a

90 systematic design within the trays (Hurlbert, 1984). On February 20, 2020 the trays were

91 removed from the refrigerator and placed on a lab bench $\left(18^{\circ} \mathrm{C}\right)$ under a fluorescent lamp. Eight

92 plants were already emerging from the soil at that time. By March 6, 117 plants had emerged 
and no others did so after that time. On March 10, all plants were moved back to the refrigerator under the lamp for cold acclimation. On March 11,30 plants for each treatment were placed on a shelf in a freezer (to provide airflow on all sides) at $-3^{\circ} \mathrm{C}$ for 0 (control), 1, 8, or 24 hours.

While the air temperature of the freezer was $-3^{\circ} \mathrm{C}$, the soil may not have reached that temperature, particularly in the 1-hour treatment. When their time in the freezer was over, the plants were moved back to the lab bench. On March 13, leaves were categorized based on their leaf area of damage (undamaged leaves were upright and medium green while damaged areas were flaccid and dark green) where $0=$ no damage, $1=1-25 \%$ damaged, $2=26-50 \%$ damaged, 3 $=51-75 \%$ damaged, and $4=76-100 \%$ damaged. Leaves were monitored daily to document date of senescence. On April 10, (after all leaves had senesced) corms were excised and assessed for survival where $0=$ dead and $1=$ alive. Live corms were solid with a tan husk and dead corms were soft and dark or decomposed leaving only the outer husk.

To document frost damage outside of the lab, I used a descriptive study with a population of E. americanum growing in a garden setting in the Village of Delhi, NY for logistical feasibility ( $\left.42^{\circ} 16^{\prime} 39^{\prime \prime} \mathrm{N}, 74^{\circ} 55^{\prime} 25^{\prime \prime} \mathrm{W}\right)$. From snowmelt (March 2, 2020) until senescence of the plants (June 9, 2020), air (at ground level) and soil temperature (5 $\mathrm{cm}$ depth) were measured where the plants were growing in the morning (daily low) and afternoon (daily high) with a soil temperature probe (HBE International, South Wayne, NJ, USA). The intention was to note the temperature when any leaf damage appeared, but none did despite a study-wide low of $-3^{\circ} \mathrm{C}$ air temperature after leaf out.

All data analyses were conducted using Minitab version 19 (Minitab, Inc., State College, PA, USA) at $\alpha=0.05$. Light measurements from the shade experiment were compared with Analysis of Variance followed by a Tukey's means comparison test. The day of year for both 
116

117

118

119

120

121

122

123

124

125

126

127

128

129

130

131

132

133

134

135

136

137

138

the start and end of senescence were compared between the shade and control plants using a paired t-test. In the frost experiment, the amount of damage, day of year of senescence, and corm survivorship were each compared among the different durations of freezing with Analysis of Variance and a Tukey's means comparison test. Finally, the temperature data from the field were used to regress air temperature against soil temperature to determine the air temperature at which the soil would reach the experimental $-3^{\circ} \mathrm{C}$ during an overnight period.

\section{Results}

In the shade experiment, each light intensity was significantly different from the others $\left(\mathrm{F}_{119,3}=404.90, \mathrm{P}<0.0001\right)$. The light intensity was $1245.9 \pm 32.2$ (mean \pm standard error) $\mu \mathrm{mol} \cdot \mathrm{m}^{-2} \cdot \mathrm{s}^{-1}$ in the control, $411.2 \pm 32.0 \mu \mathrm{mol} \cdot \mathrm{m}^{-2} \cdot \mathrm{s}^{-1}$ in the shade treatment, $281.3 \pm 26.1 \mu \mathrm{mol} \cdot \mathrm{m}^{-}$ $2 \cdot \mathrm{s}^{-1}$ in the sunflecks, and $24.49 \pm 3.41 \mu \mathrm{mol} \cdot \mathrm{m}^{-2} \cdot \mathrm{s}^{-1}$ in the background, closed canopy. The greatest absolute difference in mean light intensity was between the control and the other three conditions. Given that the shade treatment had more light than the sunflecks and background during the fully closed canopy condition, it is representative of mid-canopy closure when $E$. americanum typically begins senescing. There was no significant difference between the control and shade treatment in start date of senescence $(\mathrm{T}=0.000, \mathrm{df}=29, \mathrm{P}=1.000)$ nor end date of senescence $(\mathrm{T}=0.44, \mathrm{df}=29, \mathrm{P}=0.662$; Figure 1$)$. In both the control and the shade treatment, senescence began in late May and ended in mid-June (Figure 1).

There was significantly more leaf damage in the plants experimentally exposed to freezing than those in the control group, but no difference in the amount of leaf damage among those plants exposed to freezing for 1,8 , and 24 hours $\left(\mathrm{F}_{115,3}=187.37, \mathrm{P}<0.0001\right.$; Figure $\left.2 \mathrm{~A}\right)$.

On average, control plants had less than $25 \%$ of their leaves damaged while those that experienced any freezing had more than $75 \%$ of their leaves damaged (Figure $2 \mathrm{~A}$ ). Leaves in the 
139 control senesced significantly later than those that experienced freezing, but there was not a 140 significant difference in the time of senescence of leaves that experienced freezing $\left(\mathrm{F}_{115,3}=\right.$ 141 153.68, $\mathrm{P}<0.0001$; Figure 2B). Control leaves senesced in early April and those in the 1, 8, and 14224 hours of freezing treatments senesced in mid-March, within days of the freezing conditions.

143 Likewise, the control plants had a higher corm survival rate than those that experienced freezing, 144 but there was no difference in survivorship among the 1, 8, and 24 hour freezing treatments $145\left(\mathrm{~F}_{119,3}=99.23, \mathrm{P}<0.0001 ;\right.$ Figure $\left.2 \mathrm{C}\right)$. Four corms died in the control, 27 corms died in the 1 146 hour treatment, and all thirty corms died in both the 8 hour and 24 hour treatments (Figure 2C). 147 In the descriptive field study, there was no evidence of frost damage on any of the $E$. americanum leaves. There was only one morning after the E. americanum leaves emerged from 149 the soil that the air was $-3^{\circ} \mathrm{C}$ or lower. On 10 days, the air temperature at ground level was at or 150 below freezing. Ice crystals were visible on the leaves on four mornings. The lowest soil 151 temperature was $-1{ }^{\circ} \mathrm{C}$, which occurred on three mornings. All three of those mornings were 152 before the leaves emerged. In this field study, the air temperature would have to be $-8^{\circ} \mathrm{C}$ for the 153 soil and corms to reach $-3^{\circ} \mathrm{C}$, based on the relationship between air and soil temperature (Figure $1543)$.

155 Discussion

Early exposure to shade did not result in early senescence in E. americanum (Figure 1), 157 which rejects part of the hypothesis. Senescence in this experiment occurred at a typical time for 158 the species (Muller, 1978; Tessier, 2008), when the canopy leaves were expanding. In contrast, 159 Taylor and Pearcy (1976) noted earlier senescence in E. americanum plants growing under tree 160 species that leaf out early, though they did not show data for this observation. Also, Kim et al. 161 (2015) found that shade hastened senescence in the congener E. japonicum, but their light levels 
162 were considerably lower than those of this study, with their control being around $300 \mu \mathrm{mol} \cdot \mathrm{m}^{-2} \cdot \mathrm{s}^{-}$

1632 and their shade treatment being around $50 \mu \mathrm{mol} \cdot \mathrm{m}^{-2} \cdot \mathrm{s}^{-2}$. The results of this study suggest that if 164 canopy trees leaf out earlier than currently the norm with a warming climate (Richardson et al., 165 2006; Polgar and Primack, 2011), they will not cause a significantly early end to the growing 166 season for E. americanum. However, the shade from canopy leaves may reduce the total 167 photosynthetic capacity during that growing season (Taylor and Pearcy, 1976; Pearcy, 1988; 168 Chazdon and Pearcy, 1991). Like other spring ephemerals, E. americanum exploits the leaf-free 169 period to conduct photosynthesis at a high rate to compensate for its relatively short growing 170 season (Eickmeier and Schussler, 1993; Hull, 2002). Most sun-adapted species and leaves are not 171 successful in adapting to shaded environments (Groninger et al., 1996; Kubiske and Pregitzer, 172 1996; Lombardini, Restrepo-Diaz and Volder, 2009; Mathur, Jain and Jajoo, 2018). If the high 173 light intensity in the understory disappears early due to canopy leaf out (see Results; Kato and 174 Komiyama, 2002; Dreiss and Volin, 2013), the photosynthetic benefit of extending the late end 175 of the growing season in E. americanum may be reduced. Therefore, while early shade from 176 canopy trees should not shorten the physical growing season, it may shorten the functional 177 growing season. At first glance, the results of the experimental freezing and the field descriptive study 179 appear contradictory, with the experimental results supporting the hypothesis and the descriptive 180 results rejecting the hypothesis. However, they together tell a more complete story. It is clear

181 from the experiment that if the leaves and corm reach $-3^{\circ} \mathrm{C}$, there is significant frost damage and 182 corm death (Figure 2). Similarly, Loik et al. (2004) saw such susceptibility to frost in 183 Erythronium grandiflorum. Importantly, reaching this level of frost $\left(-8^{\circ} \mathrm{C}\right.$ air temperature) during 184 the growing season for E. americanum is probably rare under the current climate. Based on data 
185 from the nearest weather station to the field site from the National Oceanic and Atmospheric 186 Administration (NOAA, 2020), such temperatures have been reached during the above ground 187 season for E. americanum in two of the last four years and nine total times. Weather stations that 188 produce these data are typically in open areas to get data for temperature and precipitation that 189 lack interference by trees and other aboveground structures, making these stations more likely to 190 experience colder temperatures than the more sheltered microclimates where E. americanum 191 grows (Beatty, 1984; Vanwalleghem and Meenemeyer, 2019; Zellweger et al., 2020).

192 Collectively, if E. americanum starts its growing season early as the climate warms (Ladwig et 193 al., 2019; Tessier, 2019), it may suffer frost damage and potentially corm death from severe, late 194 frosts in some years (Figure 2, Gu et al., 2008; Hufkens et al., 2012). This pattern may further 195 drive the species into more sheltered and warmer microclimates in the forest (Beatty, 1984; 196 Vanwalleghem and Meenemeyer, 2019; Zellweger et al., 2020), thereby reducing its abundance 197 across gradients (Van Der Veken, Bossuyt and Hermy, 2004; Gracia et al., 2007). However, the 198 frost would have to be severe to bring about any damage to the plants and repeated across years 199 before affecting the demography of the population.

200 Barring repeated and heavy late frost, E. americanum could experience an extended 201 growing season with future climate warming. Early spring warmth causes plants of this species 202 to break bud and emerge early (Tessier, 2019) and potentially early shade from canopy trees will not cause an advanced end to the growing season (Figure 1). This extension provides greater opportunity for photosynthesis under high light, spring conditions (Lapointe, 2001; Kato and 205 Komiyama, 2002) and could lead to greater energy resources for reproduction, both vegetative 206 and sexual (Muller, 1978; Weiner et al., 2009), pending risk of frost damage to reproductive 207 structures (Thomson, 2010). Such an extension of the growing season in E. americanum would 
208 be consistent with patterns in other plant species (Christiansen, Markstron and Hay, 2011;

209 Haggerty and Galloway, 2011; Piao et al., 2019).

The results of this study lead to new questions about changes in the growing season

211 caused by climate change. First, are other spring ephemerals capable of responding to early

212 warming in the way that E. americanum can? In the northeast United States, Claytonia

213 caroliniana, and Allium tricoccum are common spring ephemerals and candidates for such study

214 (Rock, Beckage and Gross, 2004; Parker and Thomson, 2018). Second, can wintergreen species

215 (such as Dryopteris intermedia, D. marginalis, and Polystichum acrostichoides; Noodén and

216 Wagner, 1997; Tessier, 2014) break bud early with warming, withstand late frost, and extend

217 their access to high light conditions in the spring? Third, how much does canopy leaf out reduce

218 the photosynthetic rate in E. americanum and other understory species (Brach, McNaughton and

219 Raynal, 1993; Hull, 2002). Significant reductions would minimize the functional utility of

220 keeping leaves in the shade. Fourth, what determines timing of senescence in E. americanum?

221 If shade does not hasten senescence, other ecological and physiological factors could play a role

222 (Lim, Kim and Gil Nam, 2007; Gutjahr and Lapointe, 2008; Gandin et al., 2011; Liu et al., 2020)

223 In summary, late frost could limit the expansion of the growing season for $E$.

224 americanum in a warming climate if those frosts are hard enough and frequent enough to injure

225 the plants. Shade from early canopy leaves will not cause early senescence. New questions tie

226 to related species and species groups in regard to their capacity to expand their growing season

227 and functional changes in E. americanum once canopy leaves open.

\section{Acknowledgements}

The author thanks Anna Tessier for field assistance and both Douglas Holub and two

230 anonymous reviewers for constructive comments on the manuscript. 
231 Competing interests: The authors declares there are no competing interests.

232 Funding: The author declares no specific funding for this work.

233 Data availability statement

234 Data are available from figshare in August 2022: 10.6084/m9.figshare.16435584. Data can be 235 reused with permission of the author.

\section{References}

237 Austen, E.J., Lin, S.Y. and Forrest, J.R.K. (2018) 'On the ecological significance of pollen color: a case study in American trout lily (Erythronium americanum)’ Ecology, 99(4), p926-937. https://doi.org/10.1002/ecy.2164

Beatty, S.W. (1984) 'Influence of microtopography and canopy species on spatial patterns of forest understory plants', Ecology, 65(5), p1406-1419. https://doi.org/10.2307/1939121

Bertin, R.I. (2015). 'Climate change and flowering phenology in Worcester County, Massachusetts', International Journal of Plant Sciences, 176(2), p107-119. DOI:10.1086/679619

Brach, A.R., McNaughton, S.J. and Raynal, D.J. (1993). 'Photosynthetic adaptability of two fern species of a northern hardwood forest', American Fern Journal, 83(2), p47-53. https://doi.org/10.2307/1547566

CaraDonna, P J., Iler, A.M. and Inouye, D.W. (2014) 'Shifts in flowering phenology reshape a subalpine plant community', Proceedings of the National Academy of Sciences, 111(13),

253 Christiansen, D.E., Markstrom, S.L. and Hay, L.E. (2011) 'Impacts of climate change on the 
growing season in the United States', Earth Interactions, 15(33), p1-17. https://doi.org/10.1175/2011EI376.1

Di Cecco, G.J. and Gouhier, T.C. (2018) 'Increased spatial and temporal autocorrelation of temperature under climate change', Scientific Reports, 8, p14850. https://doi.org/10.1038/s41598-018-33217-0

Dreiss, L.M. and Volin, J.C. (2013). 'Influence of leaf phenology and site nitrogen on invasive species establishment in temperate deciduous forest understories', Forest Ecology and Management, 296, p1-8. https://doi.org/10.1016/j.foreco.2013.01.031

Eickmeier, W. and Schussler, E. (1993) 'Responses of the spring ephemeral Claytonia virginica L. to light and nutrient manipulations and implications for the "vernal-dam" hypothesis', Bulletin of the Torrey Botanical Club, 120(2), p157-165. doi:10.2307/2996945

Gallinat, A.S., Primack, R.B. and Wagner, D.L. (2015) 'Autumn, the neglected season in climate change research', Trends in Ecology \& Evolution, 30(3), p169-176. http://dx.doi.org/10.1016/j.tree.2015.01.004

Gandin, A., Gutjahr, S., Dizengremel, P. and Lapointe, L. (2011). ‘Source-sink imbalance increases with growth temperature in the spring geophyte Erythronium americanum', Journal of Experimental Botany, 62(10), p3467-3479. https://doi.org/10.1093/jxb/err020

Gill J.A., Alves, J.A., Sutherland, W.J., Appleton, G.F., Potts, P.M. and Gunnarsson, T.G. (2014) 'Why is timing of bird migration advancing when individuals are not?', Proceedings of the Royal Society B, 281(1774), p20132161. http://dx.doi.org/10.1098/rspb.2013.2161

Gracia, M., Montané, F., Piqué, J., and Retana, J. (2007) 'Overstory structure and topographic 
gradients determining diversity and abundance of understory shrub species in temperate forests in central Pyrenees (NE Spain)', Forest Ecology and Management, 242(2-3), p391-397. https://doi.org/10.1016/j.foreco.2007.01.056

Groninger, J.W., Seiler, J.R., Peterson, J.A. and Kreh, R.E. (1996) 'Growth and photosynthetic responses of four Virginia Piedmont tree species to shade', Tree Physiology, 16(9), p773-778. https://doi.org/10.1093/treephys/16.9.773

Gu, L., Hanson, P.J., Post, W.M., Kaiser, D.P., Yang, B., Nemani, R., Pallardy, S.G. and Meyers, T. (2008) 'The 2007 eastern US spring freeze: increased cold damage in a warming world?', BioScience, 58(3), p253-262. https://doi.org/10.1641/B580311

Gutjahr, S. and Lapointe, L. (2008) 'Carbon dioxide enrichment does not reduce leaf longevity or alter accumulation of carbon reserves in the woodland spring ephemeral Erythronium americanum', Annals of Botany, 102(5), p835-843. https://doi.org/10.1093/aob/mcn161

Haggerty, B.P. and Galloway, L.F. (2011) 'Response of individual components of reproductive phenology to growing season length in a monocarpic herb', Journal of Ecology, 99(1), p242-253. https://doi.org/10.1111/j.1365-2745.2010.01744.x

Hufkens, K., Friedl, M.A., Keenan, T.F., Sonnentag, O., Bailey, A., O'Keefe, J. and Richardson, A.D. (2012) 'Ecological impacts of a widespread frost event following early spring leaf-out', Global Change Biology, 18(7), p2365-2377. https://doi.org/10.1111/j.1365-2486.2012.02712.x

Hull, J.C. (2002) 'Photosynthetic induction dynamics to sunflecks of four deciduous forest understory herbs with different phenologies', International Journal of Plant Sciences, 163(6), p913-924. https://doi.org/10.1086/342633

Hurlbert, S.H. (1984) 'Pseudoreplication and the design of ecological field 
Experiments', Ecological Monographs, 54(2), p187-211.

https://doi.org/10.2307/1942661

Inouye, D.W. (2000) 'The ecological and evolutionary significance of frost in the context of climate change.' Ecology Letters, 3(5), p457-463. https://doi.org/10.1046/j.14610248.2000.00165.x

Inouye, D.W. (2008) 'Effects of climate change on phenology, frost damage, and floral abundance of montane wildflowers.' Ecology, 89(2), p353-362. https://doi.org/10.1890/06-2128.1

Kato, S. and Komiyama, A. (2002) 'Spatial and seasonal heterogeneity in understory light conditions caused by differential leaf flushing of deciduous overstory trees', Ecological Research, 17, p687-693. https://doi.org/10.1046/j.1440-1703.2002.00529.x

Kim, H.J., Jung, J.B., Jang, Y.L., Sung, J.H. and Park, P.S. (2015) ‘Effects of experimental early canopy closure on the growth and reproduction of spring ephemeral Erythronium japonicum in a montane deciduous forest', Journal of Plant Biology, 58, p164-174. https://doi.org/10.1007/s12374-014-0545-8

Konapala, G., Mishra, A.K., Wada, Y. and Mann, M.E. (2020) 'Climate change will affect global water availability through compounding changes in seasonal precipitation and evaporation', Nature Communications, 11, p3044. https://doi.org/10.1038/s41467-020$16757-\mathrm{w}$

Korbel, J.O. and Stegle, O. (2020) 'Effects of the COVID-19 pandemic on life scientists', Genome Biology, 21, p113. https://doi.org/10.1186/s13059-020-02031-1

Kubiske, M.E. and Pregitzer, K.S. (1996) 'Effects of elevated $\mathrm{CO}_{2}$ and light availability on the 
photosynthetic light response of trees of contrasting shade tolerance', Tree Physiology, 16(3), p351-358. https://doi.org/10.1093/treephys/16.3.351

Ladwig, L.M., Chandler, J.L., Guiden, P.W. and Henn, J.J. (2019) 'Extreme winter warm event causes exceptionally early bud break for many woody species', Ecosphere, 10(1), pe02542. https://doi.org/10.1002/ecs2.2542

Lapointe, L. (2001) 'How phenology influences physiology in deciduous forest spring Ephemerals', Physiologia Plantarum, 113(2), p151-57. https://doi.org/10.1034/j.13993054.2001.1130201.x

Lerat, S., Gauci. R., Catford, J.G., Vierheilig, H., Piché, Y. and Lapointe, L. (2002) ${ }^{114} \mathrm{C}$ transfer between the spring ephemeral Erythronium americanum and sugar maple saplings via arbuscular mycorrhizal fungi in natural stands', Oecologia, 132, p181-187. https://doi.org/10.1007/s00442-002-0958-9

Lim, P.O., Kim, H.J. and Gil Nam, H. (2007). 'Leaf senescence', Annual Review of Plant Biology, 58, p115-136. https://doi.org/10.1146/annurev.arplant.57.032905.105316

Liu, Q., Piao, S., Campioli, M., Gao, M., Fu, Y.H., Wang, K., He, Y., Li, X, and Janssens, I.A. (2020) 'Modeling leaf senescence of deciduous tree species in Europe', Global Change Biology, 26(7), p4104-4118. https://doi.org/10.1111/gcb.15132

Loik, M.E., Still, C.J., Huxman, T.E., and Harte, J. (2004) 'In situ photosynthetic freezing tolerance for plants exposed to a global warming manipulation in the Rocky Mountains, Colorado, USA.' New Phytologist, 162(2), p331-341. https://doi.org/10.1111/j.14698137.2004.01002.x

Lombardini, L., Restrepo-Diaz, H. and Volder, A. (2009) 'Photosynthetic light response and 
epidermal characteristics of sun and shade pecan leaves', Journal of the American Society for Horticultural Science, 134(3), p372-378. https://doi.org/10.21273/JASHS.134.3.372

Mathur, S., Jain. L. and Jajoo, A. (2018). 'Photosynthetic efficiency in sun and shade plants', Photosynthetica, 56, p354-365. https://doi.org/10.1007/s11099-018-0767-y

Monahan, W.B., Rosemartin, A., Gerst, K.L., Fisichelli, N.A., Ault, T., Schwartz, M.D., Gross, J.E. and Weltzin, J.F. (2016) 'Climate change is advancing spring onset across the U.S. national park system', Ecosphere, 7(10), pe01465. 10.1002/ecs2.1465

Muller, R.N. (1978) ‘The phenology, growth and ecosystem dynamics of Erythronium americanum in the northern hardwood forest', Ecological Monographs, 48(1), p1-20. https://doi.org/10.2307/2937357

Myers, K.R., Tham, W.Y., Yin, Y., Cohodes, N., Thursby, J.G., Thursby, M.C., Schiffer, P., Walsh, J.T., Lakhani, K.R. and Wang, D. (2020) 'Unequal effects of the COVID-19 pandemic on scientists' Nature Human Behaviour, 4, p880-883. https://doi.org/10.1038/s41562-020-0921-y

NOAA. (2020) National Climate Data Center [online]. Available at: http://www.ncdc.noaa.gov/ (Accessed 09 June 2020).

Noodén, L.D. and Wagner Jr, W.H. (1997) 'Photosynthetic capacity and leaf reorientation in two wintergreen ferns, Polystichum acrostichoides and Dryopteris intermedia', American Fern Journal, 87(4), p143-149. https://doi.org/10.2307/1547836

Parker, A.J. and Thomson, J.D. (2018) 'Citizen scientists document geographic patterns in pollinator communities', Journal of Pollination Ecology, 23(9), p90-97. http://dx.doi.org/10.26786/1920-7603\%282018\%2910

Pearcy, R.W. (1988) 'Photosynthetic utilisation of lightflecks by understory plants', Functional 
Plant Biology, 15(2), p223-238. https://doi.org/10.1071/PP9880223

Piao, S., Liu, Q., Chen, A., Janssens, I.A., Fu, Y., Dai, J., Liu, L., Lian, X., Shen, M. and Zhu, X. (2019) 'Plant phenology and global climate change: Current progresses and challenges', Global Change Biology, 25(6), p1922-1940. https://doi.org/10.1111/gcb.14619

Polgar, C.A. and Primack, R.B. (2011) 'Leaf-out phenology of temperate woody plants: from trees to ecosystems', New Phytologist, 191(4): p926-941. https://doi.org/10.1111/j.14698137.2011.03803.x

Richardson, A.D., Bailey, A.S., Denny, E G., Martin, C.W. and O'Keefe, J. (2006) 'Phenology of a northern hardwood forest canopy', Global Change Biology, 12(7), p1174-1188. https://doi.org/10.1111/j.1365-2486.2006.01164.x

Rock, J.H., Beckage, B. and Gross, L J. (2004) 'Population recovery following differential harvesting of Allium tricoccum Ait. in the southern Appalachians', Biological Conservation, 116(2), p227-234. https://doi.org/10.1016/S0006-3207(03)00193-9

Siccama, T.G., Bormann, F.H. and Likens, G.E. (1970) ‘The Hubbard Brook ecosystem study: productivity, nutrients, and phytosociology of the herbaceous layer', Ecological Monographs, 40(4), p389-402. https://doi.org/10.2307/1942337

Sivadasan, U., Randriamanana, T., Chenhao, C., Virjamo, V., Nybakken, L. and JulkunenTiitto, R. (2017) 'Effect of climate change on bud phenology of young aspen plants (Populus tremula. L)', Ecology and Evolution, 7(19), p7998-8007. https://doi.org/10.1002/ece3.3352

Somveille, M., Wikelski, M., Beyer, R.M., Rodrigues, A.S.L., Manica, A. and Jetz, W. 
(2020) 'Simulation-based reconstruction of global bird migration over the past 50,000 years', Nature Communications, 11, p801. https://doi.org/10.1038/s41467-020-14589-2

Stokes, R.L., Philpott, M. and Culley, T.M. (2019) 'Clonality and genetic diversity in the eastern North American spring ephemeral Erythronium americanum Ker-Gawl. (American trout lily)', The Journal of the Torrey Botanical Society, 146(3), p143-154. https://doi.org/10.3159/TORREY-D-17-00045.1

Taylor, R.J. and Pearcy, R.W. (1976) 'Seasonal patterns of the $\mathrm{CO}_{2}$ exchange characteristics of understory plants from a deciduous forest', Canadian Journal of Botany, 54(10), p10941103. https://doi.org/10.1139/b76-117

Tessier, J.T. (2008) 'Leaf habit, phenology, and longevity of 11 forest understory plant species in Algonquin State Forest, northwest Connecticut, USA', Botany, 86(5), p457-465. https://doi.org/10.1139/B08-018

Tessier, J.T. (2014) 'Reduced winter snowfall damages the structure and function of wintergreen Ferns', American Journal of Botany, 101(6), p965-969. https://doi.org/10.3732/ajb.1400181

Tessier, J.T. (2019) 'Early spring warming may hasten leaf emergence in Erythronium americanum', American Journal of Botany, 106(10), p1392-1396. https://doi.org/10.1002/ajb2.1367

Thomson, J. (1986) 'Pollen transport and deposition by bumble bees in Erythronium: Influences of floral nectar and bee grooming', Journal of Ecology, 74(2), p329-341. doi:10.2307/2260258 Thomson, J.D. (2010) 'Flowering phenology, fruiting success and progressive deterioration of 
pollination in an early-flowering geophyte.' Philosophical Transactions of the Royal Society B: Biological Sciences, 365(1555), p3187-3199. https://doi.org/10.1098/rstb.2010.0115

Van Der Veken, S., Bossuyt, B. and Hermy, M. (2004) 'Climate gradients explain changes in plant community composition of the forest understory: an extrapolation after climate warming', Belgian Journal of Botany, 137(1), p55-69. http://www.jstor.org/stable/20794538

Vanwalleghem, T. and Meentemeyer, R.K. (2009) 'Predicting forest microclimate in heterogeneous landscapes', Ecosystems, 12, p1158-1172. https://doi.org/10.1007/s10021009-9281-1

Weiner, J., Campbell, L.G., Pino, J. and Echarte, L. (2009) 'The allometry of reproduction within plant populations', Journal of Ecology, 97(6), p1220-1233. https://doi.org/10.1111/j.1365-2745.2009.01559.x

Werier, D. (2017) Catalogue of the vascular plans of New York State, Memoirs of the Torrey Botanical Society. vol. 27. Bronx, New York: The New York Botanical Garden.

Wu, C., Wang, X., Wang, H., Ciais, P., Peñuelas, J., Myneni, R B., Desai, A.R., Gough, C.M., Gonsamo, A., Black, A.T., Jassal, R.S., Ju, W., Yuan, W., Fu, Y., Shen, M., Li, S., Lui, R., Chen, J.M. and Ge, Q. (2018) 'Contrasting responses of autumn-leaf senescence to daytime and night-time warming', Nature Climate Change, 8, p1092-1096. https://doi.org/10.1038/s41558-018-0346-z

Zellweger, F., De Frenne, P., Lenoir, J., Vangansbeke, P., Verheyen, K., BernhardtRömermann, M., Baeten, L., Hédl, R., Berki, I., Brunet, J., Van Calster, H., Chudomelová, M., Decocq, G., Dirnböck, T., Durak, T., Heinken, T., Jaroszewicz, B., Kopecký, M., Máliš, F., Macek, M., Malicki, M., Naaf, T., Nagel, T.A., Ortmann-Ajkai, 
A., Petř́ik, P., Pielech, R., Reczyńska, K., Schmidt, W., Standovár, T., Świerkosz, K., Teleki, B., Vild, O., Wulf, M. and Coomes, D. (2020) 'Forest microclimate dynamics drive plant responses to warming', Science, 368(6492), p772-775.

http://doi.org/10.1126/science.aba6880 
438 Figure 1. Timing of senescence in Erythronium americanum for control plants and those 439 exposed to experimental early shade in a second growth hardwood forest in Delhi, NY USA. (A) 440 Start date of senescence. (B) End date of senescence. Statistical results are for a paired t-test. 441 Error bars indicate one standard error.

442 Figure 2. Effect of experimental exposure to frost in Erythronium americanum under laboratory 443 conditions for plants exposed to $0,1,8$, and 24 hours of $-3^{\circ} \mathrm{C}$ temperatures. (A) Leaf damage 444 where scores are $0=$ no damage, $1=1-25 \%$ damaged, $2=26-50 \%$ damaged, $3=51-75 \%$ 445 damaged, and $4=76-100 \%$ damaged. (B) Day of year of leaf senescence. (C) Percent corm 446 survivorship. Statistical results are for Analysis of Variance and Tukey's means comparison test. 447 Error bars indicate one standard error.

448 Figure 3. Relationship between air (at ground level) and soil (5 $\mathrm{cm}$ depth) temperature during 449 the spring of 2020 in a garden setting with Erythronium americanum in Delhi, NY USA.

450 Statistical results are for linear regression. 

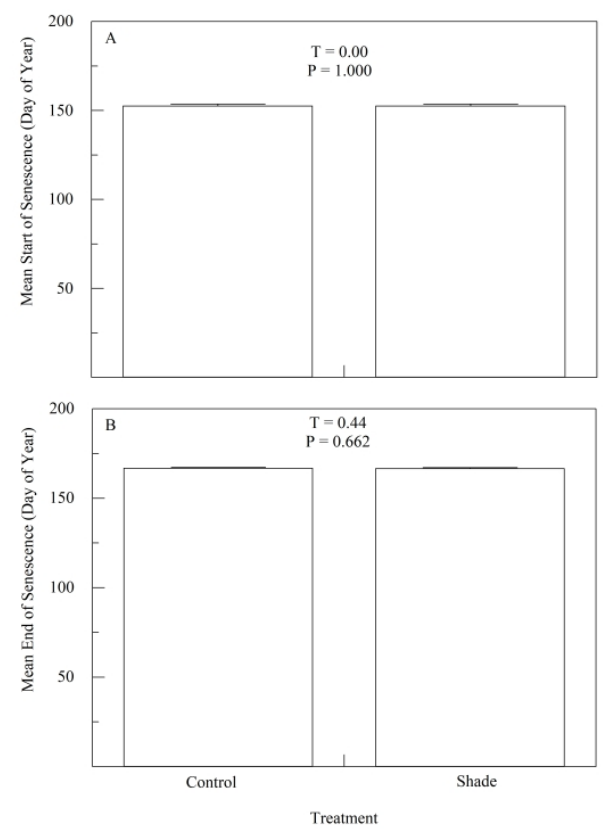

Figure 1. Timing of senescence in Erythronium americanum for control plants and those exposed to experimental early shade in a second growth hardwood forest in Delhi, NY USA. (A) Start date of senescence. (B) End date of senescence. Statistical results are for a paired t-test. Error bars indicate one standard error.

$1730 \times 1337 \mathrm{~mm}(96 \times 96 \mathrm{DPI})$ 

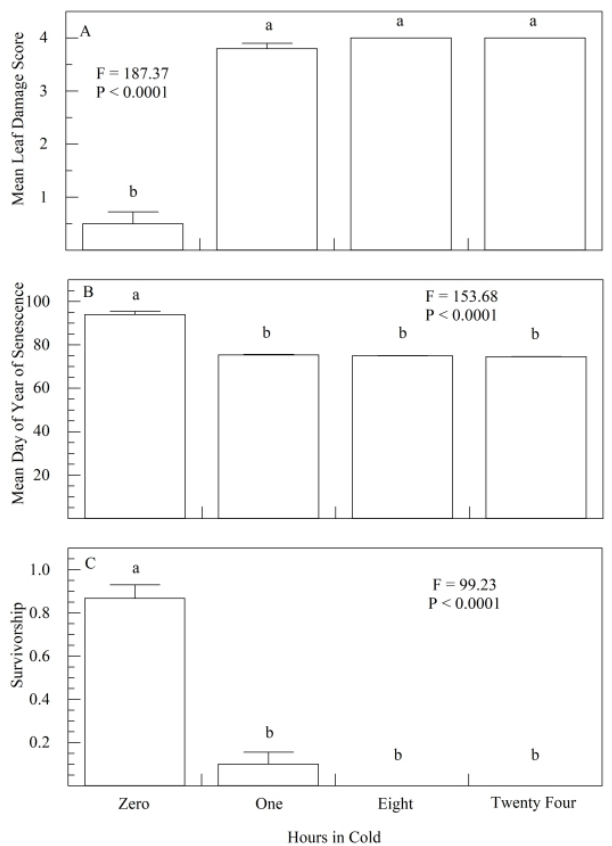

Figure 2. Effect of experimental exposure to frost in Erythronium americanum under laboratory conditions for plants exposed to $0,1,8$, and 24 hours of $-3^{\circ} \mathrm{C}$ temperatures. (A) Leaf damage where scores are $0=$ no damage, $1=1-25 \%$ damaged, $2=26-50 \%$ damaged, $3=51-75 \%$ damaged, and $4=76-100 \%$ damaged.

(B) Day of year of leaf senescence. (C) Percent corm survivorship. Statistical results are for Analysis of Variance and Tukey's means comparison test. Error bars indicate one standard error.

$1730 \times 1337 \mathrm{~mm}(96 \times 96 \mathrm{DPI})$ 


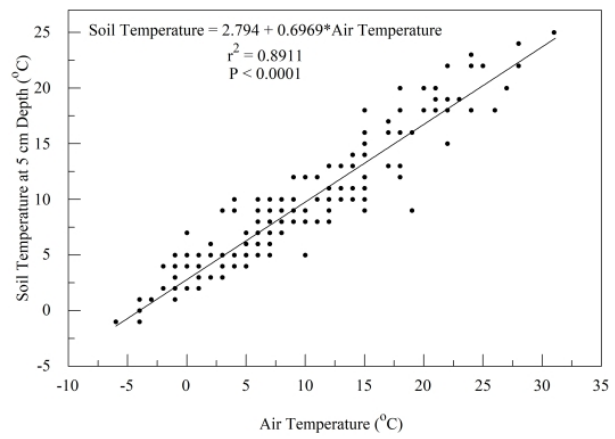

Figure 3. Relationship between air (at ground level) and soil (5 cm depth) temperature during the spring of 2020 in a garden setting with Erythronium americanum in Delhi, NY USA. Statistical results are for linear regression.

$1730 \times 1337 \mathrm{~mm}(96 \times 96 \mathrm{DPI})$ 